\title{
Application of Markov chain analysis to a fining-upward fluvial succession of the Early Permian Warchha Sandstone, Salt Range, Pakistan
}

\author{
*Shahid Ghazi ${ }^{1}$ and Nigel P. Mountney ${ }^{2}$ \\ ${ }^{1}$ Institute of Geology Punjab University, Lahore-54590, Pakistan \\ ${ }^{2}$ School of Earth and Environment, University of Leeds, Leeds, LS2 9JT, UK \\ (*Email: ghazigeo@yahoo.com)
}

\begin{abstract}
Markov chain analysis is applied to the cyclic properties and degree of ordering of lithofacies in the Early Permian (Artinskian) Warchha Sandstone. The 30 to 155 m-thick Warchha Sandstone is well exposed in the Salt Range, Pakistan and dominantly composed of sandstone, siltstone and claystone succession. Seven lithofacies have been identified on the basis of geometry, gross lithology and sedimentary structures. Lithofacies are cyclically arranged in a fining-upward pattern. A complete cycle starts with pebbly sandstone accomplished by thin layer of basal conglomerate and terminates with claystone. The non-stationary first order Markov chains have been applied statistically on vertical transition of facies using outcrop data of the Warchha Sandstone succession. Later, a chi-square test was applied to test the dependency between any two facies states in facies transitions. The results of this study reveal that the sediments of the Warchha succession were controlled by Makovian mechanism and as a whole represent fluvial succession deposited in a predictable cyclic arrangement of lithofacies.
\end{abstract}

Keywords: Fining-upward sequence, Markov chain analysis, cyclicity, Early Permian, Warchha Sandstone, Salt Range

Received: December 18, 2009

Revision accepted: April 22, 2010

\section{INTRODUCTION}

The study of cyclicity within the Warchha Sandstone highlights the rather predictable order of occurrence of fluvial facies and units of sedimentation within a succession that initially appears to be chaotic in its organisation. However, so far no analytical work has been done to understand cyclic aspects of the Warchha Sandstone. Interpretations of cyclic sedimentation form the basis of many facies models in a variety of environments (Miall 1996). Several workers (Billingsley 1961; Gingerich 1969; Krumbein and Dacey 1969; Harbaugh and Bonham-Carter 1970; Miall 1973; Khan and Casshyap 1981; Carr 1982; Walker 1984; Kulatilake 1987; Hota and Maejima 2004; Ghazi 2009) have shown that statistical techniques such as Markov chain analysis can be applied to the cyclic properties and degree of ordering of lithofacies explicitly within sedimentary successions.

Markov chain analysis is applied in geology to model discrete variables such as facies (Walker 1984). Such analysis quantifies the geologic interpretation of juxtaposition tendencies of facies in vertical stratigraphic successions. Additionally, through Walther's Law of the correlation of facies (Walker 1984; Miall 1990), it also addresses the comparison between lateral juxtaposition tendencies of facies to those that occur in a vertical sense. Markov chain analysis is based on the simple theory of whether a given lithology is independent or not of the preceding facies within a succession. The greater the dependence, the more likely that the transition from one facies type to another is part of a pattern of behaviour. This model compares the observed frequencies of facies transitions with the expected frequencies if all transitions were random. When expected frequencies are subtracted from observed frequencies, significant positive differences can be used to suggest an idealized succession of facies (Miall 1973; Cant and Walker 1976; Walker 1984) and to predict the likelihood of certain facies transitions. The aim of this statistical analysis is to recognize various common lithofacies arrangements and to determine the probability of transitions from one facies type to another, so as to aid interpretation of depositional environments and sub-environments and to develop predictive facies models for the Warchha Sandstone. Within this study, Markov chain analysis has been used to analyse the cyclicity in the Warchha Sandstone.

\section{GEOLOGICAL SETTING}

The Salt Range is $180 \mathrm{~km}$ long and $85 \mathrm{~km}$ wide range, located at the southern edge of the hydrocarbon bearing Potwar Basin (Fig.1). The Salt Range is a longitudinal eastwest trending trough, bounded on east by the Jhelum River and on west by the Indus River, on the north by the Potwar Basin and on the south by the Punjab Plain. The Early Permian rocks of the Salt Range belong to the northern 


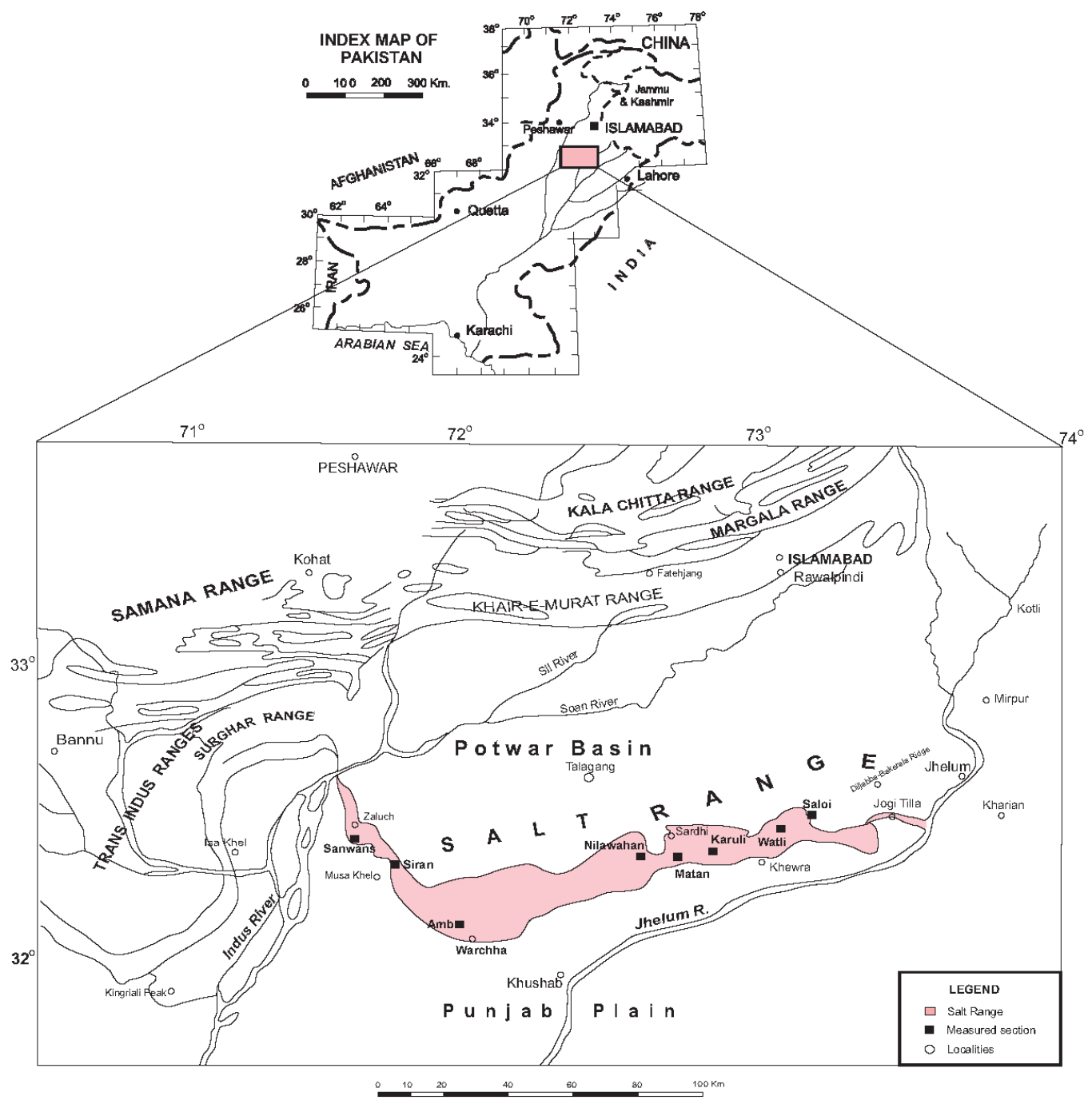

Fig. 1: Location map of the eight studied outcrop sections in the Salt Range, Pakistan

Gondwana regimes and mainly comprise of siliciclastic sedimentary rocks, known as the Nilawahan Group (Ghazi 2009). This group is classified in to four formations from base to top; the Tobra, Dandot, Warchha and Sardhai formations.

The present study is focused on the outcrop data analysis of the Warchha Sandstone from the Saloi, Watli, Karuli, Matan, Nilawahan, Am, Sarin and Sanwans areas of the Salt Range, Pakistan (Fig. 1). Warchha Sandstone is well exposed throughout the Salt Range and its thickness increases from east to west. The detailed sedimentological study has indicated that it is a fining-upward, mainly continental basin-fill sequence (Ghazi 2009). Cyclic characters of the Warchha Sandstone have been studied by applying Markov chain analysis (Gingerich 1969; Miall 1973; Cant and Walker 1976; Carr 1982; Power and Easterling 1982; Harper 1984).

\section{METHODOLOGY}

The non-stationary or homogeneous first order Markov chains have been applied on vertical transition of facies data from the eight outcrop sections in the Warchha Sandstone. In the present study the process outlined by Walker (1984) and Harper (1984) is followed. Markov chain analysis of the Warchha Sandstone is based on the assumption that vertically the lithofacies at a point ' $n$ ' depends upon the lithofacies at the proceeding point i.e. n1 (Kulatilake 1987). The data were collated and processed into transition count, transition probability, random probability and difference matrices. On the basis of the difference matrix, results in the form of facies relation diagrams were prepared to show the transition of facies states from one type to another. The cyclicity of facies was tested using a standard chi-square test. 


\section{LITHOFACIES ANALYSIS}

Seven lithofacies, arranged into a series of discrete separate fining-upward cycles, are recognised in the Warchha Sandstone (Figs. 2, 3 and Table 1) and are here described based on the classification scheme of Miall $(1985,1996)$. Table 1 shows summary of the lithofacies types encountered in the outcrop sections of Warchha Sandstone from the Salt Range, Pakistan. A complete cycle of the lithofacies observed in surficial studies of the Warchha Sandstone was condensed into seven lithofacies states from bottom to top (Fig. 3 and Table 1). Each complete cycle starts with a conglomerate or coarse-grained gravelly sandstone (facies Gt or St) at the base (Figs. 2a-c), succeeded in turn, by coarse to fine grained sandstones (facies Sp, Sh, Sr; Figs. 2b-e), parallel laminated siltstone-claystone (facies Fl) (Fig. 2f) and terminates with a claystone/mudstone intercalated with carbonaceous shale (facies Fm) (Fig. 2g). Sedimentation took place in a cyclic manner and associated sedimentary characteristics suggest that, as the deposition of each cycle proceeded, the flow intensity progressively decreased and was considerably reduced during the deposition of mudstone units that dominate the upper parts of each cycle (Ghazi 2009; Fig. 3).

The Warchha Sandstone can be informally divided into several conglomerate, sandstone and claystone units, with roughly equal proportions of sand and clay and rather less conglomerate (Ghazi 2009). Conglomerate units are composed of rounded, sub-rounded and sub-angular clasts of igneous, metamorphic and sedimentary origin, which are dark-pink, dark-brown, maroon, white and green in colour. Clasts within the conglomerates mostly range from $0.5 \mathrm{~cm}$ to $2 \mathrm{~cm}$, though large, rounded to sub-rounded, pink granite boulders up to $20 \mathrm{~cm}$ are also present. The clasts lie in poorly sorted sand, silt- and clay-grade matrix of varied composition. In places, intraformational clasts of claystone are also present. Arkose sandstone units are medium- to thick-bedded, mainly lightbrown to pinkish-white in colour, fine- to coarse-grained, poorly- to moderately-sorted, with grains that are sub-angular to sub-rounded. The sandstones commonly contain 1-3 cmthick, dark-brown, grey and green coloured claystone layers. Additionally, granule and pebble lags composed of pink granite and are common. The sandstone units are locally speckled in appearance and, in places, contain carbonaceous material. Argillaceous claystone units are red, maroon, darkbrown, grey and light-green in colour. They are commonly massive-bedded, blocky and splintery, though in places are interlaminated with thin, red, maroon, dark grey and dark green siltstone layers to form shales. A broad range of sedimentary structures is recognised, including different forms of bedding, cross-bedding, ripple marks and stratification, channels, flute casts, load casts, desiccation cracks, rain prints, cone-in-cone structures, a variety of concretions and bioturbation (Ghazi 2009). The occurrence and abundance of these structures vary in a systematic manner throughout the vertical thickness of the succession.

\section{MARKOV CHAIN ANALYSIS}

Markov chain analysis is based on the simple theory of whether a given lithology is independent or not on the lithology lying immediately below ((Miall 1973; Kulatilake 1987). The greater the dependence, the more likely that transition from one bed to another is part of a pattern of behaviour. The Markov chain model will be first order if transition of facies depends only on previous facies and higher order if transition of facies depends on more than one previous facies (Kulatilake 1987). A Markov chain will be stationary if transition of facies does not change, otherwise will be non-stationary or homogeneous.

\section{TRANSITION COUNT MATRIX}

The seven distinct lithofacies are recognised in the Warchha Sandstone - Gt, St, Sp, Sr, Sh, Fl and Fm (Miall 1996; Ghazi 2009) and expressed in 8 measured log sections were pooled and 309 transition counts were obtained and tabulated into a 7-by-7 tally count matrix (Fig. 4a) and transition count matrix. From these matrices common facies transitions can be recognized. For example, it was observed that facies Gt passes upward into facies St 42 times. The numbers to the right of matrix indicate the total number of transitions in each row. For instance, there are 51 occurrences of facies Gt passing upward into another facies. The numbers below the matrix indicate the total number of transitions in each column. For example, there are 44 occurrences of an upward transition into facies Gt.

\section{TRANSITION PROBABILITY MATRIX}

A transition probability matrix was obtained from the transition count matrix, and it records the probability of occurrence of various facies transitions within the Warchha Sandstone (Fig. 4b). This was calculated by dividing the number of transitions in each cell by the total number of transitions for the row containing the cell (i.e. the row total).

\section{RANDOM PROBABILITY MATRIX}

An independent trials or random probability matrix was then constructed, which is based on the assumption that the probability of any one facies being followed by another if the sequence was a random event (Fig. 4c). The values in each cell of this matrix were calculated using the equation:

$$
R_{i j}=S C_{j} /\left(T-S C_{i}\right)
$$

Where, $R_{i j}$ is random probability of transition from facies $\mathrm{i}$ to $\mathrm{j}, \mathrm{SC}_{\mathrm{j}}$ is random number of occurrences of facies $\mathrm{j}$ (i.e. the column total for facies $\mathrm{j}$ ), $\mathrm{T}$ is the total number of transitions for all facies (i.e. the grand total), and $\mathrm{SC}_{\mathrm{i}}$ is the number of occurrences of facies $\mathrm{i}$ (i.e. the column total for facies i). By way of example, the transition probability of facies $\mathrm{St}$ 

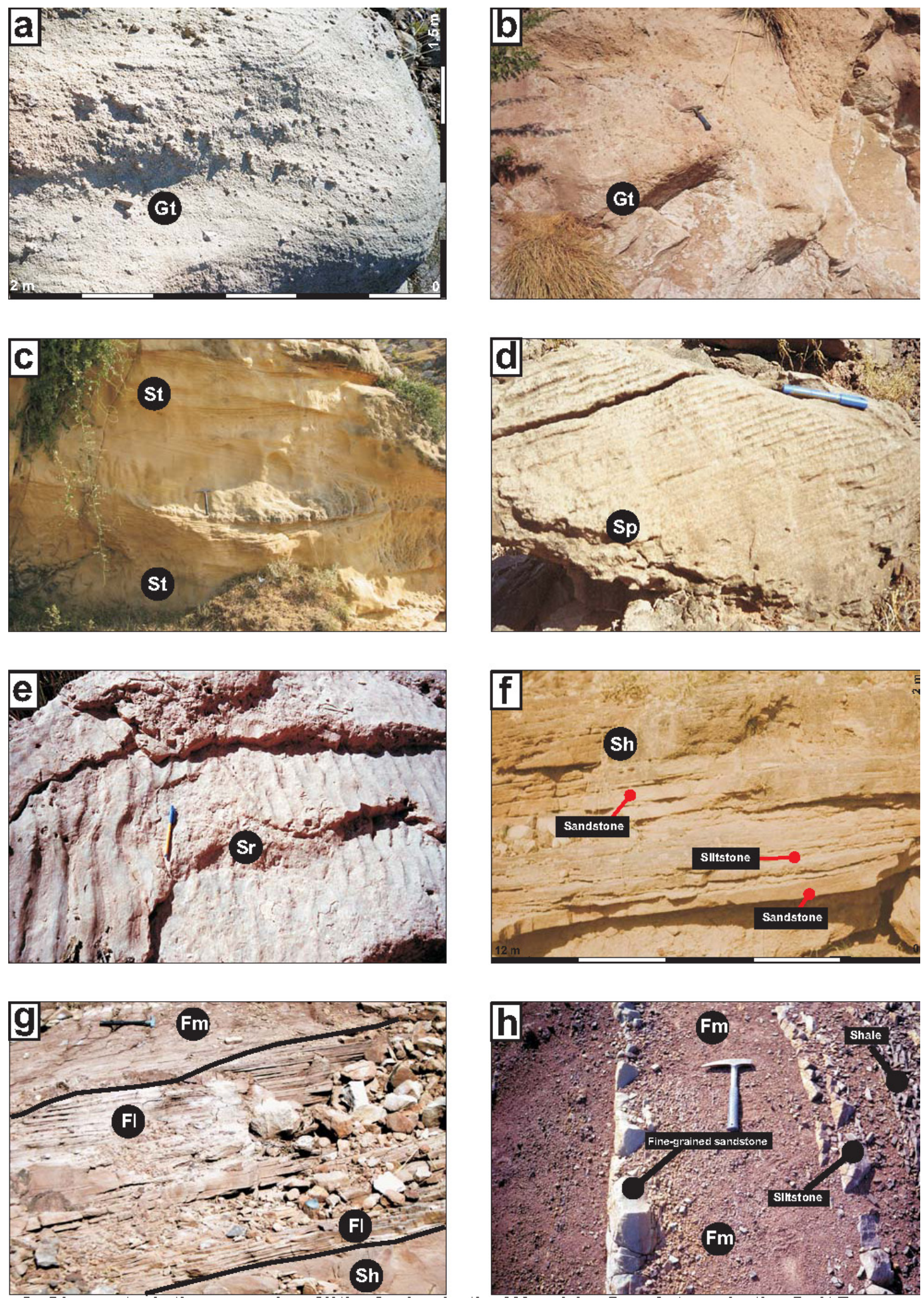

Fig. 2: Characteristic example of lithofacies in the Warchha Sandstone in the Salt Range. (a) and (b) Stratified gravely facies Gt. (c) Coarse-grained trough cross-bedded sandstone facies St. (d) Medium- to coarse-grained planar cross-bedded sandstone facies Sp. (e) Ripple cross-laminated sandstone facies Sr. (f) Horizontal bedded and laminated sandstone facies Sh. (g) Interlaminated siltstone and claystone facies Fl. (h) Massive claystone facies Fm. 
Table 1: Summary of the characteristic features of the lithofacies types encountered in the outcrop sections of Warchha Sandstone from the Salt Range, Pakistan

\begin{tabular}{l|l|}
\hline \multicolumn{1}{|c|}{ Facies } & \multicolumn{1}{c|}{ Characteristic features } \\
\hline $\begin{array}{l}\text { Massive claystone } \\
\text { /mudstone, Fm }\end{array}$ & $\begin{array}{l}\text { This facies consists of red, dark-brown, green and yellow } \\
\text { claystone and shale with occasional grey to greenishgrey } \\
\text { siltstone interbeds. The facies is generally massive, though } \\
\text { at a few horizons it contains abundant bioturbation, clay } \\
\text { balls, iron concretions, desiccation cracks, rain-drop } \\
\text { imprints and caliche nodules up to 10 cm in diameter. The } \\
\text { lower contact of this facies is typically gradational, whereas } \\
\text { the upper contact is usually sharply truncated by the erosive } \\
\text { base of the overlying cycle. }\end{array}$ \\
\hline $\begin{array}{l}\text { Parallel laminated } \\
\text { siltstone } \\
\text { claystone, Fl and }\end{array}$ & $\begin{array}{l}\text { This facies consists of laminated siltstone and/or massive } \\
\text { claystone. Its lower with facies Sh or Sr and upper contact } \\
\text { with facies Fm are gradational. Common structures include } \\
\text { clay balls and iron concretions. Interlaminated siltstone } \\
\text { horizons exhibit very small ripple marks lenticular bedding. } \\
\text { Geometrically, this facies is arranged into thin but laterally } \\
\text { extensive sheet-like bodies. }\end{array}$ \\
\hline
\end{tabular}

Very fine- to This facies consists of very fine- to medium-grained,
mediumgrained $\quad$ horizontally laminated sandstone arranged into thin beds sandstone with flat with a sheet or tabular geometry.

bedding, Sh

\begin{tabular}{l|l}
\hline $\begin{array}{l}\text { Ripple } \\
\text { laminated } \\
\text { sandstone, Sr }\end{array}$ & $\begin{array}{l}\text { This facies overlies facies Sp and consists of fine- to } \\
\text { coarse-grained sandstone, which is interlaminated with thin } \\
\text { siltstone and claystone horizons. The sandstone is medium- } \\
\text { to thick-bedded. It occurs as thin wedge-shaped bodies } \\
\text { which pinch out laterally within few metres and which } \\
\text { contain abundant ripple marks, flat bedding, and small- } \\
\text { scale trough and planar cross-stratification and load casts. } \\
\text { Clay intraclasts and concretions are common in the upper } \\
\text { parts of the deposits, as are sand balls with diameters of 50- } \\
80 \mathrm{~cm} \text {, which are a particularly diagnostic feature. }\end{array}$ \\
\hline
\end{tabular}

Medium- to coarse- This facies consists of medium- to coarse-grained, poorly grained planar sorted, arkosic sandstone arranged into lenticular or tabular cross-bedded $\quad$ sets, which are characterised internally by planarcrosssandstone, $\mathrm{Sp} \quad$ bedding. The lower contact of this facies is sharp and flat, whereas the upper contact is erosional either with facies $\mathrm{Sr}$ or Fl.

Coarse-grained trough cross-bedded sandstone, $\mathrm{St}$

This facies is most commonly overlies facies Gt and consists of medium- to very coarse-grained sandstone arranged into trough cross-bedded sets and cosets. Trough cross-bedded sets are typically $0.3-0.5 \mathrm{~m}$ thick and individual troughs are up to $1 \mathrm{~m}$ wide. The inclination of larger foresets varies from 8-16. Geometrically, this facies occurs as lenticular or wedge-shaped bodies that are pebbly in places and which are commonly arranged into stacked trough cross-bedded cosets. The lower boundary is either gradational with facies Gt or is erosional with facies Fm, whereas the upper contact is sharp and flat with facies $\mathrm{Sp}$.

Stratified gravely This facies is always present as the lowermost deposits at sandstone, Gt $\quad$ the base of each complete cycle. It consists of trough crossbedded, stratified gravels that commonly infill channel-like erosive basal surfaces. Geometrically, the facies consists of lens- or ribbon-shaped bodies, commonly interbedded with sandy deposits.

This facies is interpreted to represent the deposits of waning stage flood deposition, chiefly in overbank areas, with the majority of $\mathrm{d}$ e $\mathrm{p} \mathrm{o} \mathrm{s} \mathrm{i} \mathrm{t} \mathrm{i} \mathrm{o} \mathrm{n}$ oc c u r r i n g from suspension settling and with only limited bedload transport via weak currents.

Deposited as a plane bed under conditions of either upper or lower flow regime, either on bar top surfaces or as isolated sand sheets in overbank flood plain areas.

This facies likely represents the temporary abandonment of bars during periods of elevated water level and/or the product of deposition in areas of slack or sluggish water between bars or in overbank areas

Deposited as dunes or bars under conditions of lower flow regime.

Deposited as dunes or bars under conditions of lower flow regime.
Deposited as channel lag under conditions of lower flow regime, with sediment transport occurring via traction currents. 


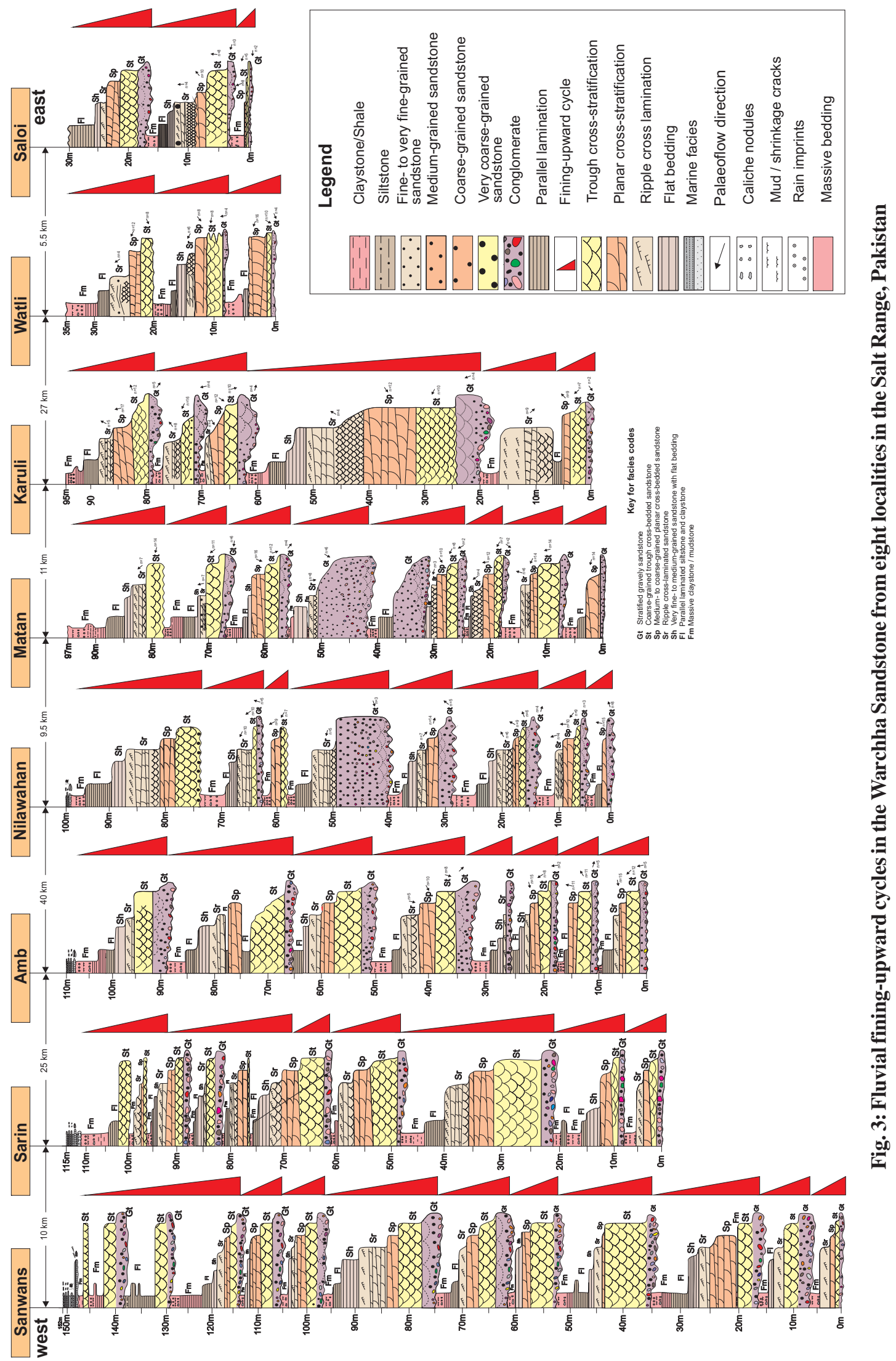


following facies $\mathrm{Gt}$ is determined by number of transitions from Gt to St (column total of facies St i.e. 50) divided by sum of all facies minus column total of facies St (309 - 44) from figure 4a (Gingerich 1968; Casshyap and Tewari 1982), which results in a probability of 0.1887 for facies St from Eq. 1 (Fig. 4c).

\section{DIFFERENCE MATRIX}

A difference matrix (Gingerich 1969) is tabulated to identify differences between observed and expected probabilities (Fig. 4d). Values used in calculating this matrix were produced by subtracting the value of each cell in figure $4 \mathrm{c}$, from the corresponding cell in figure $4 \mathrm{~b}$. The range of resultant values is +1.0 to -1.0 . Positive values indicate transitions that occur more frequently than would be the case if the facies were arranged randomly. Negative values indicate transitions that occur less frequently. The facies relationship diagram (Fig. 5) was drawn on the basis of the difference matrix results (Fig. 4d), by using only those transitions with positive values.

\section{CHI-SQUARE TEST}

The Chi-square test was applied to the transition probability matrix (Figs. 4e-f, Anderson and Goodman 1957; Billingsley 1961) as a whole for non-randomness. A null hypothesis $\left(\mathrm{H}_{0}\right)$ was set up, which states that there is no difference between any two facies states (i.e. they are derived from the same bed). The observed frequencies were collated in tabular form (Fig. 4e). The expected frequency (Fig. 4e) was calculated for each of the cells in the table (Fig. 4a), using the formula:

$$
E=\left(n_{R} \times n_{c} / N\right) \text {.. }
$$

Where $n_{R}$ is the total number of facies transitions in the row containing the cell in question (i.e. the row total), $n_{C}$ is the total number of facies transitions in the column containing that cell (i.e. the column total). $\mathrm{N}$ is the grand total of facies transitions (Fig. 4a). The Chi-square value for each of the cells was calculated using the formula:

$$
\text { Chi }- \text { square }=\chi^{2}(\text { Observed value }- \text { Expected value }) / \text { Expected value .... }
$$

Summation of the Chi-square contributions (Figs. 4e-f) gave Chi-square values of 1029.33. The larger this value, the greater the difference between any two facies states of the Warchha Sandstone. A critical value for Chi-square was determined, which allows the null hypothesis to either be accepted or rejected. The rejection or acceptance of the null hypothesis depends on the degree of freedom (d.f.) and significance level. The value of degree of freedom was calculated 29 using the formula:

$$
\text { d.f. }=(N-1)^{2}-N
$$

Where $\mathrm{N}=$ Total number of facies states in the Warchha Sandstone i.e. 7.
A significance level of 0.05 (i.e. 5\%) and degrees of freedom 29 was picked up for the facies states of the Warchha Sandstone. Since the critical value for 29 degrees of freedom at a significance level of 0.05 is 42.56 . Thus, the computed value of Chi-square exceeds the critical value at the $5 \%$ significanc 4 level (Fig. 4g), suggesting the Markovity and cyclic arrangement or non-stationarity of facies transition through time in the Warchha Sandstone.

\section{RESULTS AND INTERPRETATION OF MARKOV ANALYSIS}

The results of this statistical method for all eight measured sections of the Warchha Sandstone have been calculated on the basis of the arrangement of lithofacies. A complete cycle was deduced by positive difference elements through the matrix (Figs. 3 and 4d). The facies Fm and Fl form a closed set and become dominant with the exclusion of other facies as is evident from facies transition data (Fig. 4a). Although transition of overbank fine facies Fl or Fm to sandstone facies St and Sp are not evident in the facies relationship diagram (Fig. 5), field observations indicate that such transitions do exist (Fig. 3). Repeated occurrences of the sandstone-siltstone-facie ssuggest channel establishment and abandonment that was repetitive at a given site throughout the deposition of the Warchha Sandstone in the Salt Range region. This is most readily explained by the repeated lateral migration and avulsion of a meandering river, the channel lag and proximal channel deposits were covered by distal channel sediments, which in turn were succeeded by point bar sediments (Casshyap 1970; Hota et al. 2003). The probability of upward facies transition is rarely stationary and is instead dominantly nonstationary over the entire area of the Salt Range (Fig. 4c). This might have been due to broad regional variations in sub-depositional environments, which are not significant at the local scale (Casshyap 1975).

The individual Chi-square contributions of all these facies states show a variable degree of dependency on precursor and influence on successor states during the sedimentation of these cycles (Fig. 4g). The facies relationship diagrams (Fig. 5) drawn up from the difference matrices also show that these cycles are fining-upward asymmetric type. At various localities throughout the Salt Range, these cycles are comparable to each other and exhibit a character that might have resulted from variations in hydraulic changes by lateral shifting of the meander belts. The interbedded siltstone-claystone-carbonaceous shale sequence (facies $\mathrm{Fl}$ and Fm) at the top of most cycles in the Warchha Sandstone show a marked deviation from other states, which is due to relatively smaller values of Chi-square (91.04 and 130.30) for these facies (Fig. 4g). These low values of Chi-square values of facies Fl and Fm suggest various sub-environments developed within floodplain settings during the deposition of the Warchha Sandstone in the Salt Range region (Strahler 1963; Casshyap 1970; Hota et al. 2003). 


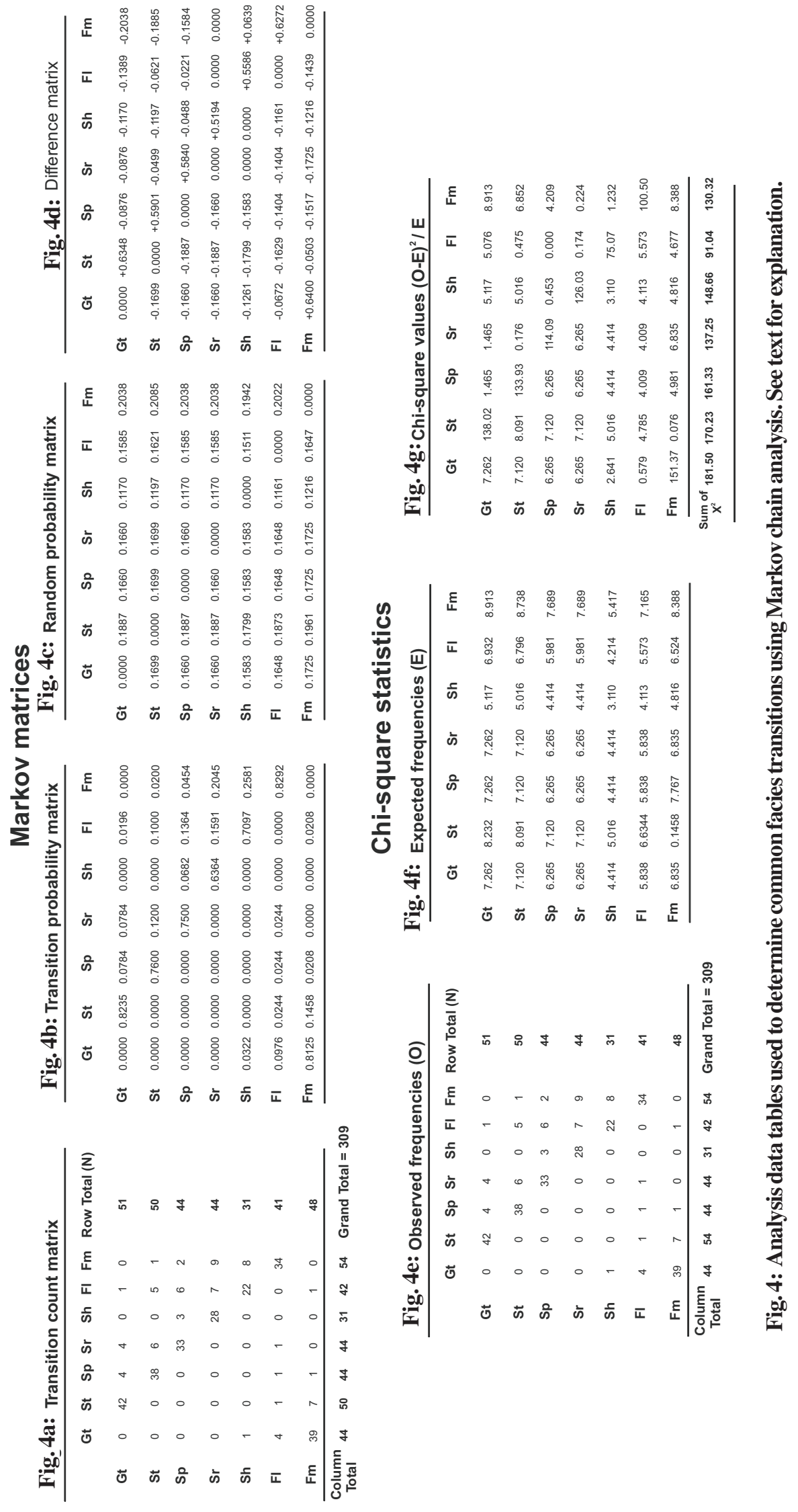




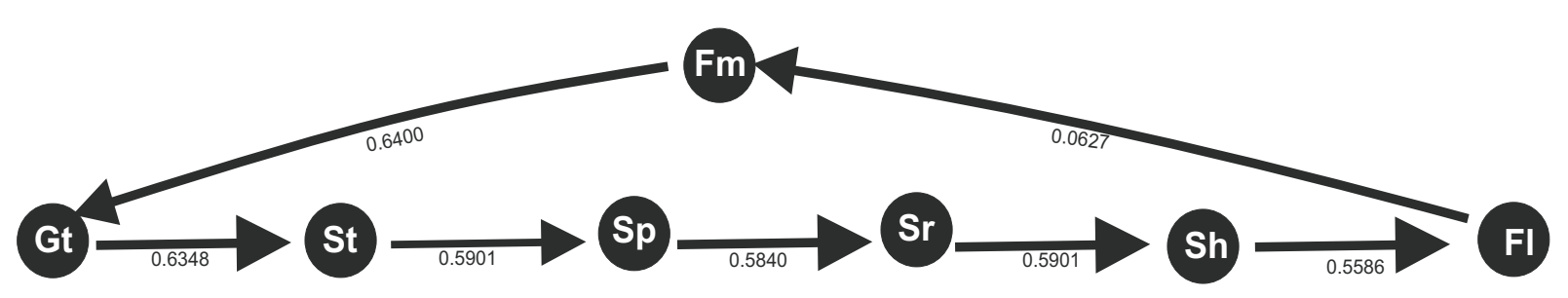

Fig. 5: Facies Relationship Diagram (FRD) based on positive values of the difference matrix recorded in Fig. 4d, showing common upward transition of facies states in clearly defined cycles in the Warchha Sandstone. Numbers indicate the probabilities of passing upward from one lithofacies to another.

\section{CONCLUSIONS}

The Early Permian Warchha Sandstone of the Salt Range exhibits a predictable cyclic arrangement of seven lithofacies. Each complete cycle of starts with a conglomerate or coarsegrained gravelly sandstone (facies $\mathrm{Gt}$ or $\mathrm{St}$ ) at the base, succeeded in turn, by coarse- to-fine-grained sandstones (facies $\mathrm{Sp}, \mathrm{Sh}, \mathrm{Sr}$ ), parallel laminated siltstone-claystone (facies Fl) and terminates with a claystone/mudstone intercalated with carbonaceous shale (facies Fm). These fining-upward cycles might have resulted from variations in hydraulic changes of lateral shifting of the meander belts. Repeated occurrence of the sandstone-siltstone-claystone facies suggests that channel establishment and abandonment was repeated many times at a given site during the sedimentation of the Warchha Sandstone. The probability of upward facies transition is non-stationary over the entire areas. Relatively low Chi-square values for facies $\mathrm{Fl}$ and Fm indicate a broad regional variation in the depositional environments that are not significant at the local scale. The siltstone-claystone-carbonaceous-shale developed either locally in a part of the floodplain or occupies the entire basin overlying the deposits of various sub environments.

\section{ACKNOWLEDGMENTS}

The first author was supported by a scholarship from the University of Punjab, Pakistan. We are grateful to Gilbert Kelling (Keele University) for providing valuable suggestions regarding the interpretation of this work. We are grateful to Tetsuya Sakai (Shimane University, Japan) and Basant Raj Adhikari (Tribhuvan University, Neapl) for critical review and valuable suggestions.

\section{REFERENCES}

Anderson, T. W. and Goodman, L. A., 1957, Statistical inference about Markov chains. Ann. Math. Statist., v. 28,89-110 pp.

Billingsley, P., 1961, Statistical methods in chains. Ann. Math. Statist., v. 32, 12-40 pp.

Cant, D. J and Walker, R. G., 1976, Development of a braidedfluvial facies model for the Devonian Battery Point Sandstone, Quebec, Canadian Jour. Earth Science, v. 13, pp. 102-119.
Carr, T. R., 1982, Log-linear models, Markov chains and cyclic sedimentation. Jour. Sediment. Petrol., v. 52 (3), pp. 905-912.

Casshyap, S. M., 1970, Sedimentary cycles and environment of deposition of the Barakar coal measures of Lower Gondwana, India. Jour. Sediment. Petrol., v. 40, pp. 1302-1317.

Casshyap, S. M., 1975, Cyclic characteristics of coal bearing sediments in the Bochumer Formation (Westphal A-2) Ruhrgebeit, Germeny. Sedimentology, v. 22, pp. 237-255.

Casshyap, S. M. and Tewari, R. C., 1982, Facies analysis and Palaeogeographic implications of a Late Palaeozoic glacial outwash deposit, Bihar, India. Jour. Sediment. Petrol., v. 52, pp. 1243-1256.

Ghazi, S., 2009, Sedimentology and stratigraphic evolution of the Early Permian Warchha Sandstone, Salt Range, Pakistan. PhD thesis, University of the Leeds, England, $362 \mathrm{p}$.

Gingerich, P. D., 1969, Markov analysis of cyclic alluvial sediments. Jour. Sediment. Petrol, v. 39, pp. 330-332.

Harbaugh, J. W. and Bonham-Carter, G. F., 1970, Computer Stimulation in Geology. Wiley and Sons, New York, 575 p.

Harper, C. W., 1984, Improved methods of facies sequence analysis. In: Facies Models, $2^{\text {nded. }}$ (Walker, R.G., Ed.) Reprint series 1, Geol. Assoc. Canada, Toronto, pp. 11-13.

Hota, R. N. and Maejima, W., 2004, Comparative study of cyclicity of lithofacies in Lower Gondwana Formations of Talchir Basin, Orissa, India: A statistical analysis of subsurface logs. Gondwana Research, v. 7, pp. 353-362.

Hota, R. N., Pandya, K. L., and Maejima, W., 2003, Cyclic sedimentation and facies organisation of the coal-bearing Barakar Formation, Talchir Gondwana Basin, Orissa, India: A statistical analysis of subsurface logs. Osaka City Uni. Jour. Geosciences, v. 46, pp. 1-11.

Khan, Z. A. and Casshyap, S. M., 1981, Entropy in Markov chain analysis of Late Palaeozoic cyclical coal measures of East Bokaro Basin, Bihar, India. Math. Geol., v. 13, pp. 153-162.

Krumbein, W. C. and Dacey, M. F., 1969, Markov chains and embedded Markov chains in Geology. Jour. Mathematical Geology, v. 1, pp. 79-86.

Kulatilake, P. H. S. W., 1987, Modelling of cyclical stratigraphy using Markov chains. Int. Jour. Min. Geol. Engg., v. 5, pp. 121-130.

Miall, A. D., 1973, Markov chain analysis applied on an ancient alluvial plain succession, Sedimentology, v. 20, pp. 347-364.

Miall, A. D., 1985, Architectural-element analysis: A new method of facies analysis applied to fluvial deposits. Earth Science Reviews, v. 22, pp. 261-308. 
Miall, A. D., 1990, Principle of sedimentary basin analysis, $2^{\text {nd }}$ edn. Springer, Berlin, Heidelberg, New York, 668 p.

Miall, A. D., 1996, The geology of fluvial deposits: Sedimentary facies, Basin analysis, and Petroleum geology. Springer-Verlag, New York, 582 p.

Power, D. W. and Easterling, P. G., 1982, Improved methodology for using embedded Markov Chains to describe cyclical sediments. Jour. Sediment. Petrol. v. 52, pp. 913924.
Strahaler, A. N., 1963, The Earth Sciences, Harper and Row, New York, $681 \mathrm{p}$.

Walker, R. G. (Ed.), 1984, General Introduction. In: Facies models, $2^{\text {nd }}$ edn. Geological Society. Canada Reprint Series 1, pp. 1-10. 